\title{
Recovery of Zinc from Used Alkali-Manganese Dry Cells
}

\author{
Masakatsu Hasegawa $^{1} \cdot$ Ryo Ueyama $^{1} \cdot$ Yoshiaki Kashiwaya $^{1} \cdot$ Tetsuji Hirato $^{1}$
}

Published online: 17 March 2015

(C) The Minerals, Metals \& Materials Society (TMS) 2015

\begin{abstract}
A new method that does not require pre-processing or the use of auxiliary materials has been investigated to recover zinc, manganese, and copper from mercury-free used alkaline-manganese dry cells. The anode product, zinc oxide, was reduced by carbon which is added to the positive reactants to improve electrical conductivity, and is also generated through thermal decomposition of separators and resin gaskets. Subsequently, metallic zinc was recovered by vaporization. With respect to the residues, copper could be separated quite easily from the steel container. With the proposed method, after the removal of zinc and copper, there is the possibility for promoting utilization of the remainder of the used dry cells as steel scrap.
\end{abstract}

Keywords Alkali-manganese dry cell $\cdot$ Zinc recovery · Steel scrap

Masakatsu Hasegawa

hasegawa.masakatsu.7r@kyoto-u.ac.jp

Ryo Ueyama

r-ueyama@jfe-steel.co.jp

Yoshiaki Kashiwaya

yoshiaki.kashiwaya@nifty.com

Tetsuji Hirato

hirato.tetsuji.2n@kyoto-u.ac.jp

1 Department of Energy Science and Technology, Graduate School of Energy Science, Kyoto University, Yoshida-honmachi, Sakyo-ku, Kyoto 606-8501, Japan

\section{Introduction}

Until the early 1990s, mercury was added to zinc-carbon and alkaline-manganese dry cells in order to suppress hydrogen gas evolution, inhibit corrosion, and improve shelf life [1]. The member companies of the Battery Association of Japan made efforts to reduce the usage of mercury in primary dry cells. Consequently, mercury was successfully eliminated in 1991 from zinc-carbon cells and in 1992 from alkaline-manganese cells [2]. At the present time in Japan, mercury-free dry cells are allowed to be disposed of as general waste with noncombustible garbage.

Before the elimination of mercury, the collection and processing of used dry batteries were carried out with the aim of preventing environmental pollution. A number of spent dry cells collected by some municipalities were sorted and recycled by companies such as Nomura Kohsan Co., Ltd. and Toho Zinc Co., Ltd., while others that were not recycled were safely landfilled. In the recycling system for mercury-containing waste, which was constructed in Itomuka by Nomura Kohsan Co., Ltd, various dry cells were sorted according to their shape, size, and weight, and then heated at temperatures between $873 \mathrm{~K}$ and $1073 \mathrm{~K}$ in a large roasting furnace for recovery of mercury by evaporation [3]. After roasting, the residue was crushed to facilitate recovery of ferrous metals by magnetic separation, while the non-ferrous fraction was utilized as a source for raw zinc material [4]. On the other hand, with respect to the safe disposal of used dry cells in landfills, several studies were carried out in Japan, Europe, and the United States. For example, the corrosion rate and mercury leaching potential of batteries buried under typical landfill conditions were investigated at Fukuoka University in Japan, and the results indicated that mercury leaking into 


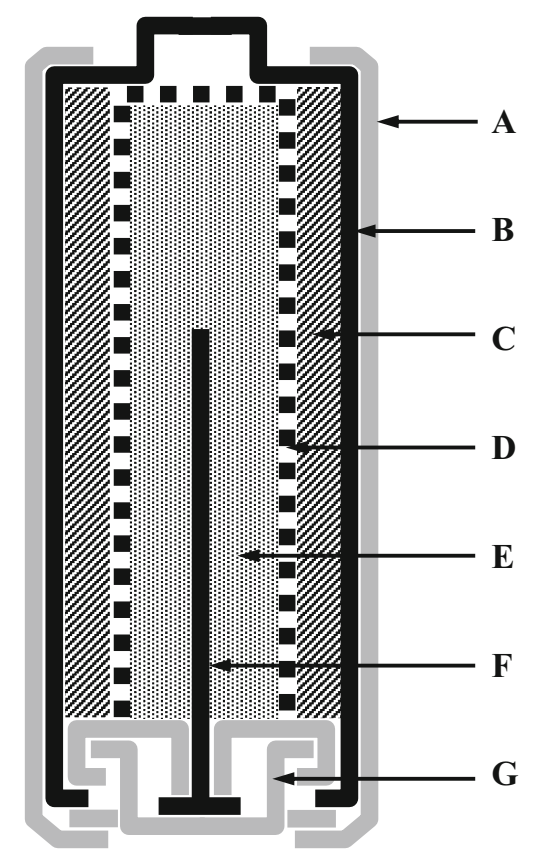

Fig. 1 Schematic diagram of used alkali-manganese dry cell. $A$ label, $B$ steel container; $\mathrm{Fe}-\mathrm{Ni}$ alloy, $C$ positive reactant; $\mathrm{MnO}_{2}+-$ $\mathrm{Mn}(\mathrm{OH})_{2}+\mathrm{MnOOH}+$ carbon mixture, $D$ separator; vinylon, $E$ gelled anode; $\mathrm{Zn}+\mathrm{ZnO}$ mixture, $F$ current collector; $\mathrm{Cu}-\mathrm{Zn}$ alloy, $G$ resin gasket

leachate over a 10 -year period was no more than $0.1 \%$ of the initial content [5].

Recently, there has been a strong incentive to recycle spent primary dry cells from the viewpoint of effective utilization of natural resources. A schematic diagram of a typical alkali-manganese dry cell is shown in Fig. 1. The chemical reaction that accompanies the discharge in this cell is expressed by the following equations:

$$
\mathrm{MnO}_{2}+\mathrm{Zn}+\mathrm{H}_{2} \mathrm{O} \rightarrow \mathrm{Mn}(\mathrm{OH})_{2}+\mathrm{ZnO}
$$

or

$2 \mathrm{MnO}_{2}+\mathrm{Zn}+\mathrm{H}_{2} \mathrm{O} \rightarrow 2 \mathrm{MnOOH}+\mathrm{ZnO}$

Zinc and manganese are the main metallic components in the roasting residue after mercury removal from used battery scrap. It has been reported that zinc and manganese can be dissolved completely by leaching with sulfuric acid solution. The separation and recovery of zinc from the filtrate of the leaching solution can then be achieved by sulfide precipitation [6]. However, as mentioned above, with the elimination of mercury from primary dry cells, the use of less complex recycling systems might be possible. Based on this consideration, a number of hydrometallurgical or pyrometallurgical studies have been conducted on the recycling of mercury-free dry cells.

Shin et al. investigated the recovery of manganese from spent alkaline-manganese batteries [7]. The procedure consisted of mechanical separation of metal-containing particles followed by a leaching process. It was found that $99 \%$ of zinc and $97 \%$ of manganese were successfully extracted from the spent battery powder by leaching at $333 \mathrm{~K}$ for $60 \mathrm{~min}$ with $3 \mathrm{kmol} / \mathrm{m}^{3} \mathrm{H}_{2} \mathrm{SO}_{4}$ and $\mathrm{H}_{2} \mathrm{O}_{2}$. Saotome et al. suggested a vacuum-aided recycling technology, which was based on disassembling, sorting, and recovering a specific material through the use of different evaporation temperatures for each material [8]. He et al. studied the recycling of spent alkaline-manganese dry batteries by means of a dry-wet combination method [9]. Metal shells from the batteries were pre-processed using mechanical means, and valuable substances in the batteries were then extracted by a vacuum technique and hydrometallurgy.

In Europe, extensive trials have been conducted for recycling spent batteries in a steelmaking electric arc furnace [1]. The melting of steel scrap within the electric arc furnace is an example of one of the world's largest and most successful recycling operations. The batteries were added into the charge bucket together with the steel scrap and fed to the furnace without any pre-processing or additional operator requirements. It was reported that manganese dioxide in the batteries would normally be dissolved in the slag, while the majority of the zinc would vaporize into the furnace off-gases and collect as zinc oxide in the filter plant dust. As shown in Fig. 1, however, the presence of residual copper, which was used as a current collector, ultimately restricted the addition of batteries to the electric arc furnace, because copper could not be removed from molten steel by the regular refining processes [10].

The present study was aimed at developing a more simple method for the recovery and separation of zinc, manganese, and copper from mercury-free used alkalinemanganese dry cells. As shown in Fig. 1, carbon is added to the positive reactants to improve electrical conductivity, and organic materials are used for the separator and gasket. This suggests that there is a possibility for developing a recycling technology for dry cells without the need for preprocessing or the addition of auxiliary materials, by reducing zinc oxide with carbon or with carbon and hydrogen generated through thermal decomposition of the organic materials, and subsequently recovering metallic zinc by vaporization. Figure 2 shows the Ellingham diagram for the Standard Free Energy change for some oxidation reactions as a function of temperature. As shown in this figure, zinc oxide can be reduced by carbon at temperatures above $1226 \mathrm{~K}$, while metallic zinc can be reoxidized by water vapor at temperatures below $1503 \mathrm{~K}$. Based on these considerations, a study was conducted on the recovery of zinc from used alkaline-manganese dry cells at 1123, 1223, 1323,1423 and $1523 \mathrm{~K}$. 


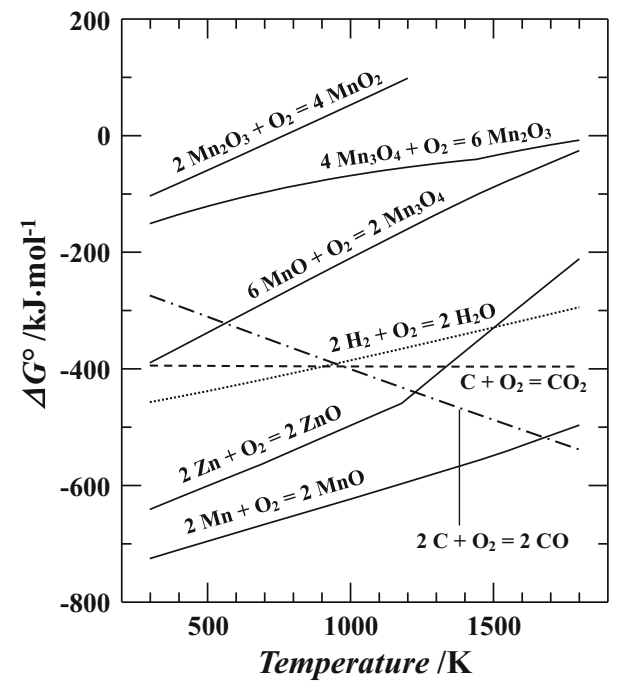

Fig. 2 Ellingham diagram for zinc oxide and manganese oxides

Table 1 Contents of metallic elements in a type LR6 of alkalinemanganese dry cell

\begin{tabular}{lllllll}
\hline Element & $\mathrm{Zn}$ & $\mathrm{K}$ & $\mathrm{Mn}$ & $\mathrm{Fe}$ & $\mathrm{Cu}$ & $\mathrm{Ni}$ \\
\hline Mass\% & 17.6 & 4.1 & 24.3 & 14.4 & 0.8 & 0.1 \\
\hline
\end{tabular}

\section{Experimental Aspects}

The average concentrations of metallic elements in the LR6 type of alkaline-manganese dry cells used in this study are summarized in Table 1. All cells were discharged completely before experimental runs. The experimental procedure consisted of removing moisture from the cells and subsequently recovering metallic zinc at elevated temperature through reduction and vaporization.

Figure 3 shows a schematic diagram of the experimental setup for the removal of water vapor. A $\mathrm{SiC}$ resistance furnace was fitted with a glass reaction tube of $35 \mathrm{~mm}$ outer diameter, $32 \mathrm{~mm}$ inner diameter, and $600 \mathrm{~mm}$ in length. The reaction tube was connected to a measuring cylinder of $12 \mathrm{~mm}$ outer diameter, $10 \mathrm{~mm}$ inner diameter and $300 \mathrm{~mm}$ in length. During an experimental run, in order to condense water vapor in the measuring cylinder but not in the reaction tube, the reaction tube outside the furnace was heated with a tape heater at a temperature above $373 \mathrm{~K}$, while the cylinder was kept at $273 \mathrm{~K}$ in a mixture of water and ice. A glass crucible containing a used dry cell was heated up to $673 \mathrm{~K}$ over a period of $4 \mathrm{~h}$ under a stream of nitrogen at a flow rate of $50 \mathrm{ml} / \mathrm{min}$. The relationship between amount of water collected within the measuring cylinder and experimental time was recorded. Temperature of the sample was measured with a K-type thermocouple located just above the crucible. The furnace temperature was controlled using another thermocouple

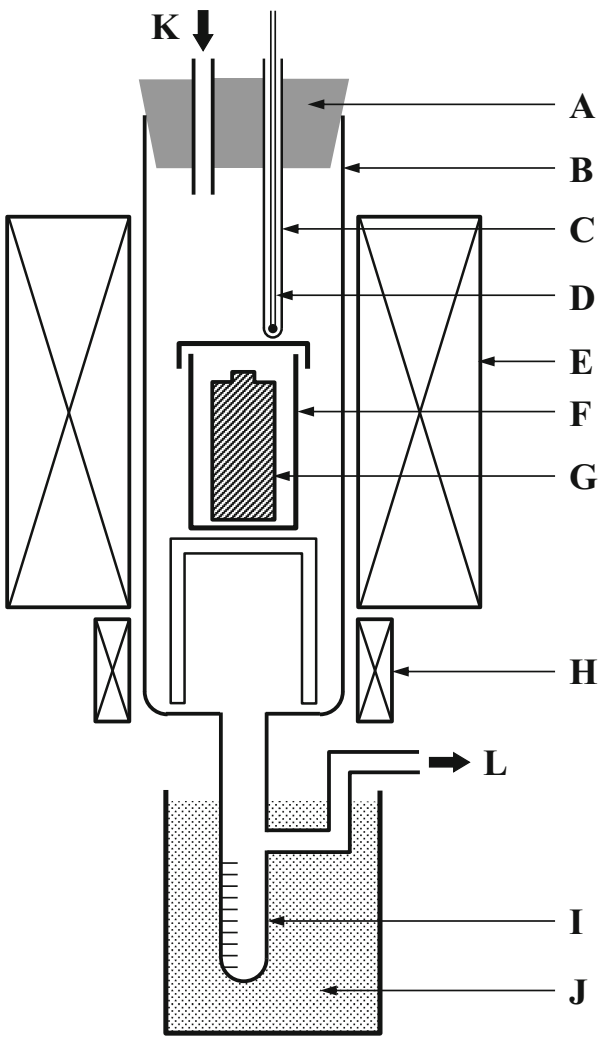

Fig. 3 Experimental setup for water removal. A rubber stopper, $B$ glass reaction tube, $C$ alumina sheath, $D$ K-type thermocouple, $E \mathrm{SiC}$ resistance furnace, $F$ glass crucible, $G$ used dry cell, $H$ tape heater, $I$ measuring cylinder, $J$ mixture of water and ice, $K$ gas inlet, $L$ gas outlet

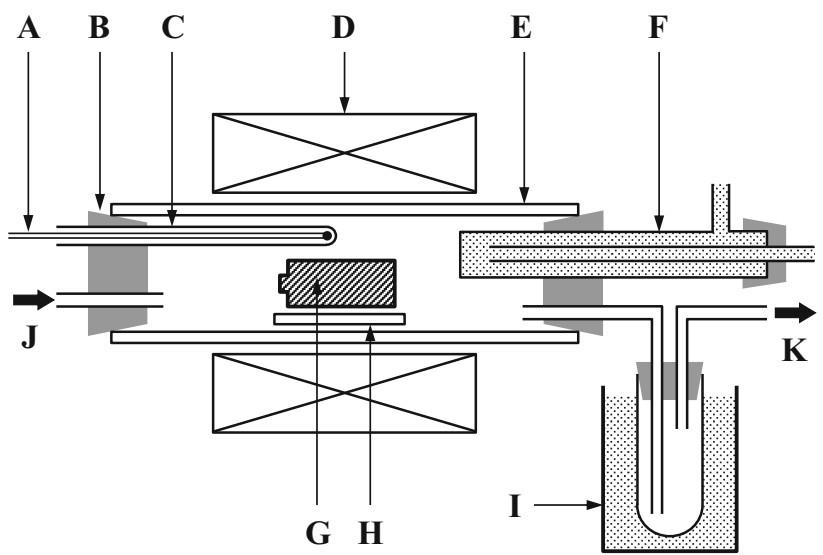

Fig. 4 Experimental apparatus for zinc recovery. A Pt-PtRh13 thermocouple, $B$ rubber stopper, $C$ alumina sheath, $D \mathrm{SiC}$ resistance furnace, $E$ alumina reaction tube, $F$ water-cooled copper pipe, $G$ used dry cell, $H$ alumina boat, $I$ cold trap, $J$ gas inlet, $K$ gas outlet

and a PID temperature regulator. The overall errors in temperature measurement and control were estimated to be less than $\pm 3 \mathrm{~K}$.

Figure 4 gives a schematic illustration of the experimental apparatus for zinc recovery. A SiC resistance 
furnace was equipped with an alumina reaction tube of $37 \mathrm{~mm}$ outer diameter, $30 \mathrm{~mm}$ inner diameter, and $600 \mathrm{~mm}$ in length. A water-free alkaline-manganese dry cell was placed on an alumina boat, and heated to 1123 , $1223,1323,1423$, or $1523 \mathrm{~K}$ at a heating rate of $10 \mathrm{~K} / \mathrm{min}$ under a stream of nitrogen at a flow rate of $50 \mathrm{ml} / \mathrm{min}$. Temperature was measured with a Pt-PtRh13 thermocouple located just above the sample. A typical temperature profile in an experimental run is shown in Fig. 5. A water-cooled copper pipe, $12 \mathrm{~mm}$ outer diameter, $10 \mathrm{~mm}$ inner diameter, and $300 \mathrm{~mm}$ in length and closed at one end, was located in the reaction tube in order to condense metallic zinc vapor. During an experimental run, the exhaust gas passed through a cold trap and was analyzed intermittently with micro gas chromatography. After each experimental run, zinc condensed on the copper pipe was dissolved in hydrochloric acid, and the amount of zinc was analyzed by means of an inductively coupled plasma spectrometer.

\section{Experimental Results and Discussion}

As illustrated in Fig. 1, used alkaline-manganese dry cells contain electrolytic aqueous solution in a separator and manganese hydroxides as reaction products. The variation of water removal rates with time is shown in Fig. 6. Water

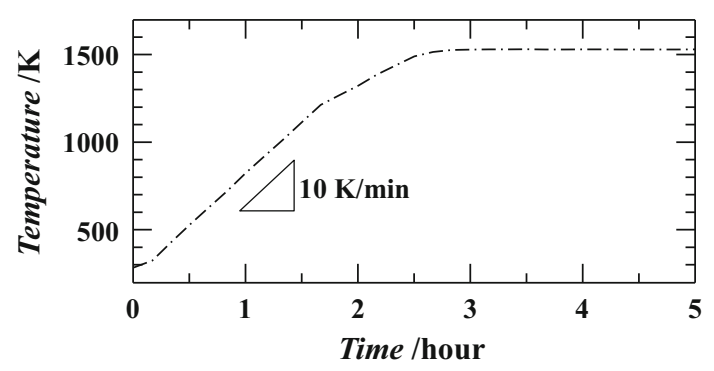

Fig. 5 Typical temperature profile during an experimental run for zinc recovery

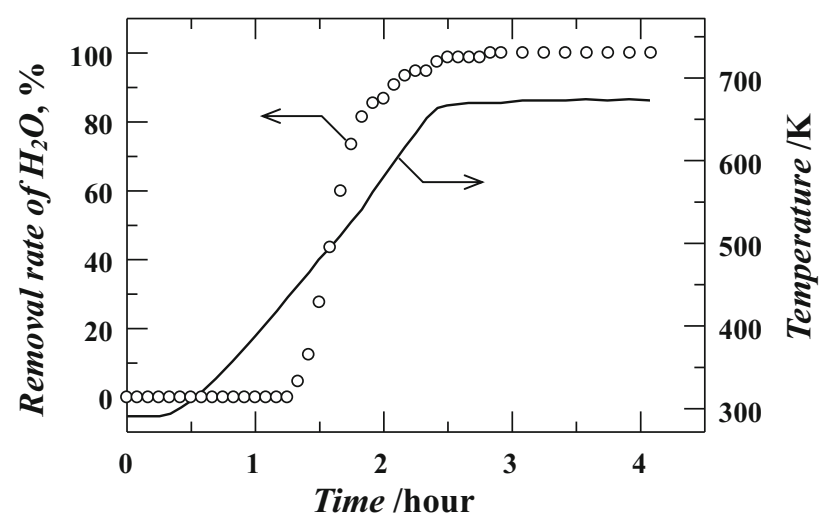

Fig. 6 Water removal rate plotted against experimental time removal from a used dry cell began about $430 \mathrm{~K}$. This observation would correspond to vaporization of $\mathrm{H}_{2} \mathrm{O}$ from the electrolytic aqueous solution with softening and leaking of the resin gasket. The amount of $\mathrm{H}_{2} \mathrm{O}$ collected in the measuring cylinder increased drastically with an increase in temperature, and $\mathrm{H}_{2} \mathrm{O}$ in the cell was removed completely after the sample temperature reached $673 \mathrm{~K}$. These experimental results were in good agreement with the literature data that show manganese hydroxides, $\mathrm{Mn}(\mathrm{OH})_{2}$ and $\mathrm{MnOOH}$, decompose to manganese oxides and water vapor at $460 \mathrm{~K}$ [11] and temperature between $470 \mathrm{~K}$ and $620 \mathrm{~K}$ [12], respectively.

Figure 7 shows the volume fractions of gaseous components in the exhaust gas during zinc recovery from a used dry cell, in which water was removed as mentioned above. The generation of $\mathrm{CO}_{2}$ was observed at a temperature below $1200 \mathrm{~K}$. In this temperature range, the Ellingham diagram suggests that $\mathrm{CO}_{2}$ is generated through the reduction of manganese oxides by carbon present in the positive reactant:

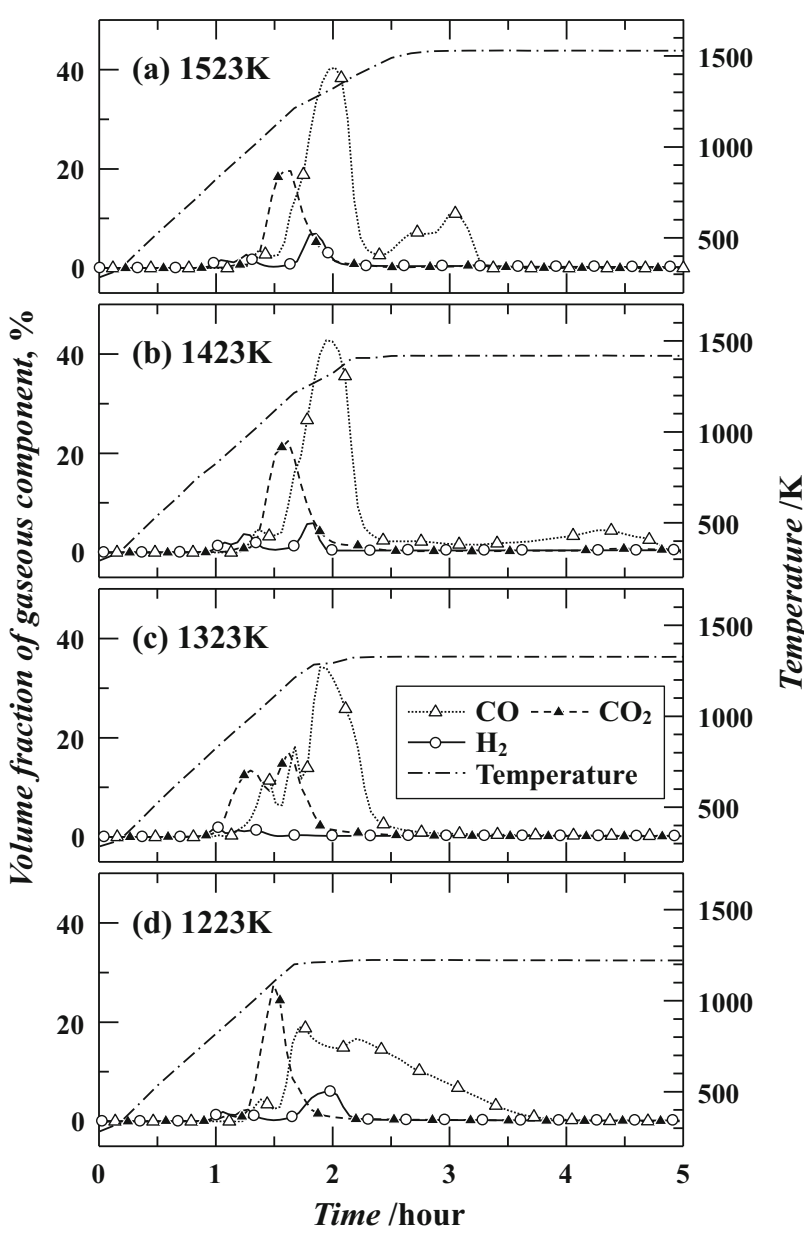

Fig. 7 Concentrations of $\mathrm{CO}, \mathrm{CO}_{2}$, and $\mathrm{H}_{2}$ generated during zinc recovery 


$$
\begin{aligned}
& 4 \mathrm{MnO}_{2}+\mathrm{C}=2 \mathrm{Mn}_{2} \mathrm{O}_{3}+\mathrm{CO}_{2} \\
& 6 \mathrm{Mn}_{2} \mathrm{O}_{3}+\mathrm{C}=4 \mathrm{Mn}_{3} \mathrm{O}_{4}+\mathrm{CO}_{2} \\
& 2 \mathrm{Mn}_{3} \mathrm{O}_{4}+\mathrm{C}=6 \mathrm{MnO}+\mathrm{CO}_{2}
\end{aligned}
$$

At temperatures around $1250 \mathrm{~K}$, the generation of $\mathrm{H}_{2}$ was observed. This would correspond to thermal decomposition of organic materials, which consisted of carbon, hydrogen, and oxygen and were used as separators and gaskets in the dry cells. Based on thermodynamic considerations for thermal decomposition of organic material [13], and on the assumption that, at elevated temperature, one mole of organic material generates $n<\mathrm{C}>$ moles of solid carbon and gas of volume, $V$, containing $n \mathrm{CO}, n \mathrm{CO}_{2}$, $n \mathrm{H}_{2}, n \mathrm{H}_{2} \mathrm{O}, n \mathrm{O}_{2}$ and $n \mathrm{CH}_{4}$ mol of each gaseous species, the reactions between the chemical species can be expressed as follows:

$$
\begin{aligned}
\mathrm{C}(\text { solid })+ & (1 / 2) \mathrm{O}_{2}=\mathrm{CO} \\
\log K(6) & =\log P_{\mathrm{CO}}-(1 / 2) \log P_{\mathrm{O}_{2}} \\
= & 4.578+5.835 \times 10^{3} / T[14] \\
\mathrm{C}(\text { solid })+ & \mathrm{O}_{2}=\mathrm{CO}_{2} \\
\log K(8)= & \log P_{\mathrm{CO}_{2}}-\log P_{\mathrm{O}_{2}} \\
= & 4.371 \times 10^{-2}+2.059 \times 10^{4} / T[14] \\
\mathrm{H}_{2}+(1 / 2) \mathrm{O}_{2}= & \mathrm{H}_{2} \mathrm{O} \\
\log K(10)= & \log P_{\mathrm{H}_{2} \mathrm{O}}-\log P_{\mathrm{H}_{2}}-(1 / 2) \log P_{\mathrm{O}_{2}} \\
= & 4.829 \times 10^{-1}-9.790 \times 10^{-1} \log T \\
& +1.251 \times 10^{4} / T[14] \\
\mathrm{C}(\operatorname{solid})+ & 2 \mathrm{H}_{2}=\mathrm{CH}_{4} \\
\log K(12)= & \log P_{\mathrm{CH}_{4}}-2 \log P_{\mathrm{H}_{2}} \\
= & 3.413-2.677 \log T+3.610 \times 10^{3} / T[14]
\end{aligned}
$$

The mass balances for carbon, hydrogen, and oxygen, respectively, are given as follows:

$$
\begin{aligned}
& X_{\mathrm{C}}=n<\mathrm{C}>+n \mathrm{CO}+n \mathrm{CO}_{2}+n \mathrm{CH}_{4} \\
& X_{\mathrm{H}}=2 n \mathrm{H}_{2}+2 n \mathrm{H}_{2} \mathrm{O}+4 n \mathrm{CH}_{4} \\
& X_{\mathrm{O}}=n \mathrm{CO}+2 n \mathrm{CO}_{2}+n \mathrm{H}_{2} \mathrm{O}+2 n \mathrm{O}_{2}
\end{aligned}
$$

where $X_{i}$ represents mole fraction of component $i$. Assuming ideal behavior of gaseous species, the partial pressures, $P_{i}$, of gaseous components, $i\left(i=\mathrm{CO}, \mathrm{CO}_{2}, \mathrm{H}_{2}\right.$, $\mathrm{H}_{2} \mathrm{O}, \mathrm{O}_{2}$ and $\left.\mathrm{CH}_{4}\right)$ are related to $n i$ and $V$ through the following relationship:

$P i V=n i R T$

By combining Eq. (17) with Eqs. (14), (15), and (16), respectively, the following relationships are obtained:
$X_{\mathrm{C}}=n<\mathrm{C}>+(V / R T)\left(P_{\mathrm{CO}}+P_{\mathrm{CO}_{2}}+P_{\mathrm{CH}_{4}}\right)$

$X_{\mathrm{H}}=(V / R T)\left(2 P_{\mathrm{H}_{2}}+2 P_{\mathrm{H}_{2} \mathrm{O}}+4 P_{\mathrm{CH}_{4}}\right)$

$X_{\mathrm{O}}=(V / R T)\left(P_{\mathrm{CO}}+2 P_{\mathrm{CO}_{2}}+P_{\mathrm{H}_{2} \mathrm{O}}+2 P_{\mathrm{O}_{2}}\right)$

The gas phase is present at a total pressure, $P_{\text {total }}$ where:

$P_{\mathrm{CO}}+P_{\mathrm{CO}_{2}}+P_{\mathrm{H}_{2}}+P_{\mathrm{H}_{2} \mathrm{O}}+P_{\mathrm{O}_{2}}+P_{\mathrm{CH}_{4}}=P_{\text {total }}$

During an experiment under a stream of nitrogen, the following relationship is valid:

$P_{\text {total }}+P_{\mathrm{N}_{2}}=1$

These 8 Eqs. (7), (9), (11), (13), (18), (19), (20) and (21) involve 8 unknowns, i.e. $V, n<\mathrm{C}>, P_{\mathrm{CO}}, P_{\mathrm{CO}_{2}}, P_{\mathrm{H}_{2}}, P_{\mathrm{H}_{2} \mathrm{O}}$, $P_{\mathrm{O}_{2}}$ and $P_{\mathrm{CH}_{4}}$. Hence values for these unknowns can be calculated by solving these equations simultaneously for a particular temperature, a total pressure and known compositions, $X_{\mathrm{C}}, X_{\mathrm{H}}$, and $X_{\mathrm{O}}$. Figure 8 shows the calculated values for the mole numbers of chemical species generated through the thermal decomposition of vinylon $\left(X_{\mathrm{C}}=0.318\right.$, $X_{\mathrm{H}}=0.545$ and $X_{\mathrm{O}}=0.136$ ) used as a separator. Solid carbon, $\mathrm{CO}$, and $\mathrm{H}_{2}$ were the main components at $1250 \mathrm{~K}$, and their mole numbers were fairly insensitive to the variation of total pressure. This implied that the calculation results were independent of the gas flow rate of nitrogen. On the other hand, the amounts of the other species were negligible. Based on these results, there is an opportunity to use solid carbon and/or $\mathrm{H}_{2}$ generated through thermal decomposition of organic materials to reduce metallic oxides.

At temperatures above $1200 \mathrm{~K}$, the generation of $\mathrm{CO}$ is shown in Fig. 7. In this temperature range, manganese oxide and zinc oxide were reduced by carbon, which was not only added to the positive reactant but also generated through decomposition of organic materials.

$\mathrm{Mn}_{3} \mathrm{O}_{4}+\mathrm{C}=3 \mathrm{MnO}+\mathrm{CO}$

$\mathrm{ZnO}+\mathrm{C}=\mathrm{Zn}+\mathrm{CO}$

On the other hand, the condensation of $\mathrm{H}_{2} \mathrm{O}$ was not observed in the cold trap. This observation indicated that

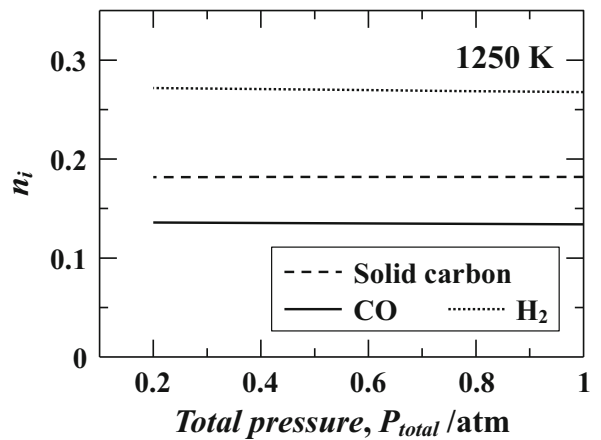

Fig. 8 Calculated values for amounts of solid carbon, $\mathrm{CO}$ and $\mathrm{H}_{2}$ through thermal decomposition of one mole of vinylon 
the reduction of manganese oxide and zinc oxide should be attributed to carbon rather than hydrogen.

Table 2 gives the amount of zinc in the material collected on the copper pipe analyzed by means of an inductively-coupled plasma spectrometer. When the zinc recovery rate is $100 \%, 4.21 \pm 0.18 \mathrm{~g}$ of metallic zinc can be obtained from a dry cell used in this study. The zinc recovery rates are plotted against time in Fig. 9. At $1123 \mathrm{~K}$, the amount of zinc collected in $4 \mathrm{~h}$ was very small and only $20 \%$ of zinc was recovered after $9 \mathrm{~h}$. Based on considerations from the Ellingham diagram, pure zinc oxide cannot be reduced by carbon below $1226 \mathrm{~K}$. Therefore,

Table 2 Amount of zinc in the material collected on the copper pipe

\begin{tabular}{lll}
\hline Temperature $(\mathrm{K})$ & Time $(\mathrm{h})$ & Amount of zinc $(\mathrm{g})$ \\
\hline 1123 & 4 & $0.195 \pm 0.007$ \\
1123 & 9 & $0.777 \pm 0.004$ \\
1223 & 3 & $1.974 \pm 0.011$ \\
1223 & 4 & 2.432 \\
1223 & 5 & $2.317 \pm 0.099$ \\
1223 & 6 & 2.365 \\
1223 & 9 & $3.018 \pm 0.019$ \\
1323 & 3 & $2.116 \pm 0.010$ \\
1323 & 4 & 2.361 \\
1323 & 5 & $2.747 \pm 0.120$ \\
1323 & 6 & 2.950 \\
1323 & 9 & $3.537 \pm 0.083$ \\
1423 & 3 & $3.206 \pm 0.027$ \\
1423 & 4 & $3.653 \pm 0.169$ \\
1423 & 5 & $3.873 \pm 0.169$ \\
1423 & 6 & 4.065 \\
1523 & 3 & $3.757 \pm 0.029$ \\
1523 & 4 & 3.715 \\
1523 & 5 & $3.628 \pm 0.178$ \\
1523 & 6 & 3.855 \\
\hline
\end{tabular}

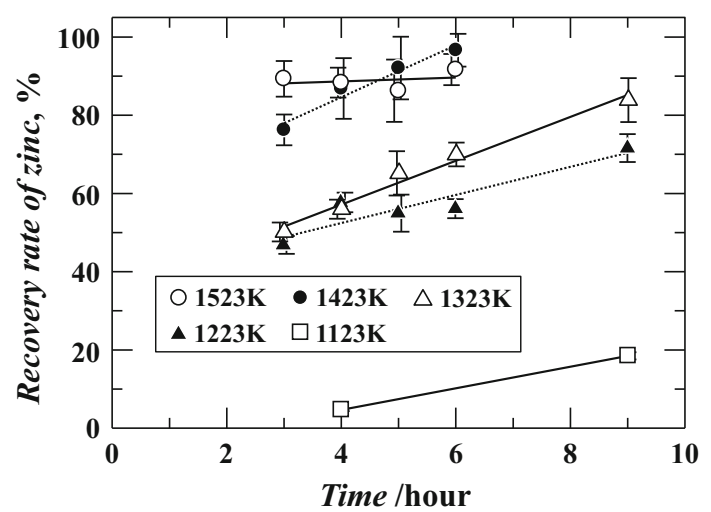

Fig. 9 Changes in recovery rate of zinc over time zinc recovered at $1123 \mathrm{~K}$ was metal that remained in the used dry cells. It is noteworthy that the boiling point of zinc is $1180 \mathrm{~K}$ [15]. Relatively, slow vaporization at $1123 \mathrm{~K}$ was caused by the small amount of remaining metallic zinc and the value for the vapor pressure of $5.61 \times 10^{4} \mathrm{~Pa}$ [16], lower than one atmosphere pressure. The recovery rates of zinc increased drastically with an increase in the sample temperature. At 1223 and $1323 \mathrm{~K}$, the recovery rate increased as the time was prolonged, and at temperatures above $1423 \mathrm{~K}$ more than $85 \%$ of zinc could be recovered in $4 \mathrm{~h}$.

The Ellingham diagram also indicated that zinc could be reoxidized by $\mathrm{CO}$ during solidification at temperature below $1226 \mathrm{~K}$. In order to confirm such reoxidation, the zinc collected on the copper pipe was analyzed by X-ray diffraction (XRD). Figure 10 shows the XRD patterns. As seen in this figure, the peaks for $\mathrm{ZnO}$ could be observed as well as those for metallic zinc in the material obtained at 1423 and $1523 \mathrm{~K}$. By applying a simple calibration-curve method to the XRD patterns, the $\mathrm{ZnO}$ contents given in Table 3 were determined. As would be expected, the $\mathrm{ZnO}$

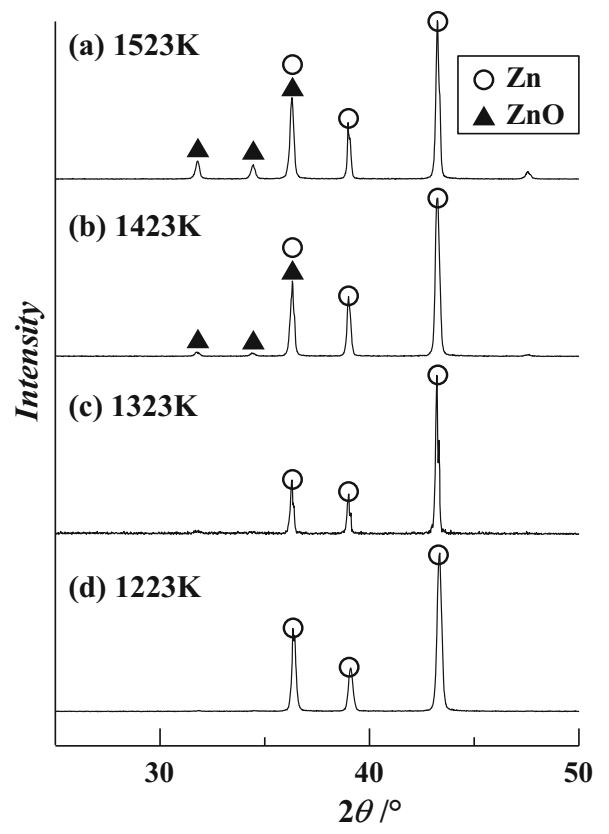

Fig. 10 X-ray diffraction patterns of the material collected on the copper pipe

Table $3 \mathrm{ZnO}$ contents in the material collected on the copper pipe

\begin{tabular}{lc}
\hline Temperature $(\mathrm{K})$ & ZnO content (mass\%) \\
\hline 1123 & 0.03 \\
1223 & 1.18 \\
1323 & 2.74 \\
1423 & 12.04 \\
\hline
\end{tabular}


(a)

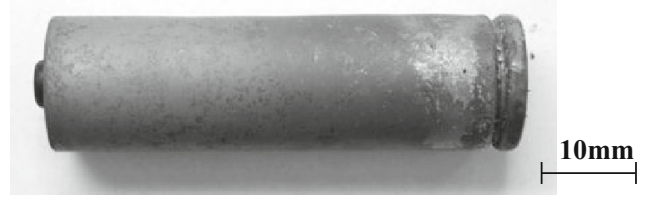

(b)

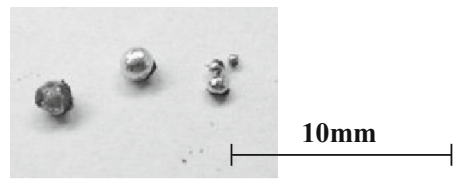

Fig. 11 Residues after zinc recovery at $1323 \mathrm{~K}$

contents increased with an increase in temperature at which zinc was vaporized. These experimental results suggest that zinc should be vaporized at a relatively low temperature and that metallic vapor should be condensed quickly in order to prevent the reoxidation of zinc.

Figure 11 shows the residues after zinc recovery at $1323 \mathrm{~K}$. The steel canister contained $\mathrm{MnO}$ produced through reduction of the positive reactants in the dry cells. This observation was in agreement with the Ellingham diagram, which indicated that $\mathrm{MnO}$ could not be reduced by carbon at temperatures below $1678 \mathrm{~K}$. Based on the fact that $90 \%$ of manganese has been used as an auxiliary raw material in steel plants [16], steel canisters with $\mathrm{MnO}$ could be returned to steelmaking or utilized as a raw material for ferromanganese. Liquid droplets of copper were observed outside steel canisters, as shown in Fig. 11b. As mentioned previously, copper used as a current collector in the gelled anode restricted the amount of used cells that could be recycled in steelmaking processes [1]. In this study, copper could be separated quite easily from steel canisters due to the vaporization of the reduced anode by thermal decomposition of the resin gaskets. Thus with the proposed zinc recovery method from used dry cells, there is a possibility for promoting utilization of zinc and copper as sources for raw materials, and canisters as steel scrap.

\section{Conclusions}

An experimental study has been conducted with the objective of recovering metallic components from used alkaline-manganese dry cells. The results obtained can be summarized as follows:

1. Water contained in the electrolyte and present as manganese hydroxides could be removed completely at $673 \mathrm{~K}$
2. Solid carbon, gaseous hydrogen, and carbon monoxide were generated through thermal decomposition of the organic materials used as separators and gaskets.

3. Zinc oxide was apparently reduced by carbon rather than hydrogen, and more than $85 \%$ of the zinc could be recovered at temperatures above $1423 \mathrm{~K}$.

4. Residual copper could be easily separated from the steel container.

Acknowledgments Helpful comments, suggestions, discussion, and encouragement were given by the late Dr. Masanori Iwase, Professor, Kyoto University, and Dr. Alexander McLean, Professor Emeritus, University of Toronto, and these are gratefully acknowledged.

\section{References}

1. Watson N (2001) Primary battery recycling in Europe. Used battery collection and recycling. Elsevier, Oxford, pp 177-223

2. Fujimoto K (2001) Battery collection and recycling in Japan. Used battery collection and recycling. Elsevier, Oxford, pp 87-104

3. Murase J, Matsubara S (2013) Recycling of industrial waste containing mercury by sole refinery plant in Japan. J Environ Saf 4:107-109. doi:10.11162/daikankyo.ES12H0801

4. Hirayama N, Gotoh S, Yajima T (1987) Recovery of mercury and other metals from used dry cells - The CJC demonstration plant in Hokkaido, Japan. Conserv Recycl 10:237-241

5. Yanase R, Hirano F, Matsufuji Y, Hanashima M (2004) Behavior of mercury in disposed dry batteries after 10 years in landfill site. J Jpn Soc Waste Manag Experts 15:96-104

6. Kiuchi H, Ayuta F (1995) Separation and recovery of zinc from used battery scrap. Shigen-to-Sozai 111:1017-1021

7. Shin SM, Kang JG, Yang DH, Sohn JS (2007) Development of metal recovery process from alkaline manganese batteries in sulfuric acid solutions. Mater Trans 48:244-248. doi:10.2320/ matertrans. 48.244

8. Saotome Y, Nakazawa Y, Yamada Y (1999) Disassembling and materials recovering process of alkaline manganese dry batteries by vacuum-aided recycling systems technology. Vacuum 53:101-104

9. He Q, Li J, Wang J (2011) A study on the technology and equipment for recycling spent zinc-manganese dry batteries. Appl Mech Mater 43:748-751. doi:10.4028/www.scientific.net/AMM. 43.748

10. Katayama H, Mizukami Y (1996) Recycling of ferrous scrap. Materia Jpn 35:1283-1289

11. Moore TE, Ellis M, Selwood PW (1950) Solid oxides and hydroxides of manganese. J Am Chem Soc 72:856-866

12. Lee JA, Newnham CE, Stone FS, Tye FL (1980) Thermal decomposition of manganese oxyhydroxide. J Solid State Chem 31:81-93

13. Seetharaman S (ed) (2014) Treatise on process metallurgy, vol 1 Process fundamentals. Elsevier, Oxford, pp 636-638

14. Kubaschewski O, Alcock CB (1979) Metallurgical thermochemistry, 5th edn. Pergamon Press, Oxford, pp 378-384

15. Kubaschewski O, Alcock CB, Spencer PJ (1993) Materials thermochemistry, 6th edn. Pergamon Press, Oxford, pp 258-323

16. Nishiyama $T$ (2009) Rare Metal Resour. Maruzen, Tokyo, pp 123-125 